\title{
GOOD FAITH ACQUISITION OF OWNERSHIP IN A CAR UNDER GERMAN LAW (ACCORDING TO THE ITALIAN JUDGE): NOTE TO TRIBUNALE DI IVREA, 20 APRIL 2019, Nº 416
}

\author{
ACQUISTO A NON DOMINO DELLA PROPRIETÀ DI UN \\ AUTOVEICOLO AI SENSI DEL DIRITTO TEDESCO (SECONDO \\ IL GIUDICE ITALIANO): NOTA A TRIBUNALE DI IVREA, \\ 20 APRILE 2019, N. 416
}

\author{
EnNio Piovesani \\ PhD Student \\ Università degli Studi di Torino / Universität zu Köln
}

Recibido: 07.04.2020 / Aceptado: 04.05.2020

DOI: https://doi.org/10.20318/cdt.2020.5746

\begin{abstract}
The commented decision by the Tribunale di Ivrea, of 20 April 2019, contains three maxims: (i) under Art. 51(1) of Law 218/1995, good faith acquisition of ownership in a movable good (in that case, a motor vehicle) is governed by the law of the State where the good is situated; (ii) the court-appointed expert's opinion on foreign law goes beyond the assigned tasks where it examines the evidence and applies the rules to the facts, tasks which are not entrusted to the expert and reserved to the judge; (iii) the concept of good faith in $\S 932$ BGB is comparable to that in Art. 1147 C.C.
\end{abstract}

Keywords: motor vehicles, rights in rem, lex rei sitae, expert opinion, good faith acquisition.

Riassunto: La decisione in commento del Tribunale di Ivrea, del 20 aprile 2019, contiene tre massime: (i) ai sensi dell'art. 51, co. 1, L. 218/1995, l'acquisto a non domino della proprietà del bene mobile (nel caso di specie, un autoveicolo) è disciplinato dal diritto dello Stato in cui il bene è situato; (ii) la relazione del CTU sul diritto straniero va oltre l'incarico conferito, laddove giunge a valutare le prove ed applicare le norme alla fattispecie, compito non affidato al consulente e riservato al giudicante; (iii) il concetto di buona fede di cui al $\S 932$ BGB è paragonabile al concetto di buona fede di cui all'art. 1147 c.c.

Parole chiave: autoveicolo, diritti reali, lex rei sitae, consulenza tecnica, acquisto a non domino.

Summary: I. Facts. II. Issues. 1. Jurisdiction. 2. Applicable Law. 3. (...) and Content thereof. A) Transfer of Ownership. B) (...) from a Person Without Title. C) (...) of Cars and Stolen Goods. D) (...) to the Good Faith Acquirer. 4. Transaction Chain. A) Caia and Tizio. B) Tizio and the Car Dealer. C) The Car Dealer and Hans. III. Final Remarks.

\section{Facts ${ }^{1}$}

1. The facts underlying the commented decision ${ }^{2}$ can be summarized as follows:

\footnotetext{
${ }^{1}$ I am grateful for advice from Dr. Lukas Rademacher.

2 Tribunale di Ivrea, 20 April 2019, № 416, Il Caso.it, Sez. Giurisprudenza, 23584 - pubb. 13.5.2020.
} 
- on 4 August 2012, Caia reported to the Italian authorities that, on 20 July 2012, Tizio had stolen her Lamborghini in Italy, by taking advantage of a drive test she had organized with the view of selling the car;

- actually, Tizio had not stolen, but rather bought the car from Caia, though paying the price with an uncovered cheque;

- soon after, Tizio sold the car to a German car dealer;

- on 28 November 2012, Hans bought the car from the same car dealer;

- at the time of the sale, the car's registration book still mentioned Caia as the owner;

- on 30 November 2012, Hans registered the car in Germany;

- in January 2014, Hans decided to resell the car and, to that aim, he had an online ad published;

- in February 2014, after having learned about the ad, Caia reported Hans to the German (and the Dutch) authorities for theft;

- the German authorities seized the car and instituted criminal proceedings against Hans;

- Hans sued Caia before the Tribunale di Ivrea, asking the judge to declare in his favour and in accordance with German law, the good faith acquisition of ownership in the car;

- Caia failed to enter an appearance and the judge thus declared her to be in default ("contumace").

\section{Issues}

2. Considering that the dispute was characterized by elements of extraneousness, the judge preliminarily asserted jurisdiction and then determined German law as the law applicable to the dispute. The judge thus examined the content of German law and ultimately upheld the claimant's plea.

\section{Jurisdiction}

3. Since the defendant was domiciled in Italy, the judge correctly asserted jurisdiction under Art. 4 of Reg. (EU) $N^{\circ}$ 1215/2012 (Brussels Ibis Regulation) ${ }^{3}$. Besides, only the Italian judge (and not the German judge) could have settled the dispute. In fact, the Brussels Ibis Regulation's jurisdictional "menu" does not offer a specific forum in the case of disputes on rights in rem in movables. ${ }^{5}$ Moreover, in principle, when the Brussels Ibis Regulation applies, following Art. 5 thereof, heads of jurisdiction provided for in the autonomous international procedural law of the single Member States should not apply. ${ }^{6}$ In particular, as concerns the German law system, when the Regulation applies, paragraph (§) 23 of the German Regulation of Civil Procedure (die Zivilprozessordnung - ZPO), cannot apply; the provision confers jurisdiction on the judge of the place (in Germany) where the defendant who is not domiciled in Germany has his belongings. ${ }^{7}$

\footnotetext{
${ }^{3}$ Regulation (EU) N ${ }^{\circ} 1215 / 2012$ of the European Parliament and of the Council of 12 December 2012 on jurisdiction and the recognition and enforcement of judgments in civil and commercial matters, OJEU L 351 of 20 December 2012, p. 1, ELI: http://data.europa.eu/eli/reg/2012/1215/oj.

${ }^{4}$ A. Briggs, “Arbitration and the Brussels Regulation Again”, Lloyd's Mar. \& Comm. L., 2015, p. 288.

${ }^{5}$ For sake of completeness, it must be noted that, in the case of claims for the recovery, based on ownership, of a cultural object, Art. 7(4) of the Brussels Ibis Regulation gives jurisdiction to the courts of the place where the object is situated; and that, jurisdiction over disputes on rights in rem in movables may well be prorogated under Arts. 24 and 25 of the same Regulation. Incidentally, it is pertinent to recall the proposal made by the Commission, during the recasting of Regulation (EC) No 44/2001, of vesting with jurisdiction "as regards rights in rem or possession in movable property, the courts for the place where the property is situated". See EuRopean Commission, Proposal for a Regulation of the European Parliament and of the Council on jurisdiction and the recognition and enforcement of judgments in civil and commercial matters (Recast), Brussels, 14.12.2020, COM (2020) 748 final.

6 See H. van Lith, "Jurisdiction - General Provisions", in A. Dickinson/E. Lein (eds.), The Brussels I Regulation Recast, Oxford, Oxford University Press, 2015, para. 3.08; see also, with reference to the Brussels I Regulation, ECJ, 19 December 2013, C-9/12, Corman-Collins SA v. La Maison du Whisky SA, paras. 21-22.

7 See G. Toussaint, "ZPO § 23", in V. Vorwerk/C. Wolf (eds.), BeckOK ZPO, München, C.H. Beck, version of 1 January 2020, para. 19; C. HeINRICH, “ZPO § 23”, in H.-J. Musielak/W. Voit (eds.), Zivilprozessordnung mit Gerichtsverfassungsgesetz,
} 


\section{Applicable Law}

4. The judge determined the law applicable to the dispute in accordance with the Italian autonomous private international law contained in Law 218/1995, the Reform of the Italian System of Private International $\mathrm{Law}^{8}$.

5. Besides, there appear to be no general international or Union substantive or private international law instruments in matters of rights in rem in movables. In fact, these matters are: excluded from the scope of the 1980 Vienna Convention on the Sale of Goods ${ }^{9}$ (see Art. 4); excluded from the 1955 Hague Convention on the law applicable to international sales of goods ${ }^{10}$ (see Art. 5, $\mathrm{N}^{\circ}$ 3); governed by the 1958 Hague Convention on the Law Applicable to Transfer of Title in Case of International Sale of Tangible Movable Goods, which has not entered into force yet ${ }^{11}$ (see Art. 3); excluded, though not expressly, from the 1980 Rome Convention on the Law Applicable to Contractual Obligations ${ }^{12}$ and from the Rome I Regulation ${ }^{13} .^{14}$

6. Having considered that the car was situated in Germany, the judge determined German law as the law applicable to the dispute. In fact, as the same judge observed, under Art. 51(1) of Law 218/1995, "on the basis of the locus rei sitae principle" 15 , disputes on rights in rem in movables and immovables are governed by the law of the State where the things are situated.

7. However, the judge did not consider three relevant aspects: (i) the matters governed by the applicable law; (ii) the issue of the so-called mobile conflict (conflit mobile); and (iii) the institution of renvoi.

8. (i) Among the matters governed by the law applicable under Art. 51(1) of L. 218/1995, are disputes in matters of good faith acquisition of ownership ${ }^{16}$ in registered movables (such as cars), ${ }^{17}$ but also remedies (which the title holder can use to protect his legal position) against third parties. ${ }^{18}$

9. (ii) Italian autonomous private international law does not address the issue of mobile conflict, that is to say the issue of which law applies when movables are moved from one State to another. In

München, Franz Vahlen, 2019, para. 18; R. PAtZinA, “ZPO § 23”, in T. Rauscher/W. Krüger, Münchener Kommentar zur Zivilprozessordnung mit Gerichtsverfassungsgesetz und Nebengesetzen, München, C.H. Beck, 2016, para. 23; see also A. JUNKER, Internationales Zivilprozessrecht, München, C.H. Beck, 2016, § 5 paras. 25, § 6 paras. 24 and § 21 para. 33.

${ }^{8}$ Law 219/1995, of May $31^{\text {st }}$, Riforma del sistema italiano di diritto internazionale privato, Gazzetta Ufficiale Serie Generale $\mathrm{N}^{\circ} 128$ of 3 June 1995 - Suppl. Ordinario $\mathrm{N}^{\circ}$ 68, ELI: https://www.gazzettaufficiale.it/eli/id/1995/06/03/095G0256/sg.

${ }^{9}$ United Nations Convention on Contracts for the International Sale of Goods, UNTS, 1988, Vol. 1489, p. 3.

${ }^{10}$ Convention on the law applicable to international sales of goods, UNTS, 1964, Vol. 510, p. 148.

${ }^{11}$ Italy ratified the Convention. See Law 1622/1960, of December $7^{\text {th }}$, Ratifica ed esecuzione della Convenzione sulla legge applicabile al trasferimento della proprietà in caso di vendita a carattere internazionale di beni mobili corporali, firmata all'Aja il 15 aprile 1958, Gazzetta Ufficiale Serie Generale N 5 of 7 January 1961, ELI: https://www.gazzettaufficiale.it/eli/ id/1961/01/07/060U1622/sg.

${ }^{12}$ Convention on the law applicable to contractual obligations, UNTS, 1991, Vol. 1605, p. 59.

${ }^{13}$ Regulation (EC) $\mathrm{No}^{\circ} 593 / 2008$ of the European Parliament and of the Council of 17 June 2008 on the law applicable to contractual obligations (Rome I), OJEU L 177 of 4 July 2008, p. 6, ELI: https://data.europa.eu/eli/reg/2008/593/oj.

${ }^{14}$ See P. Lagarde, "Droits réels et obligations. La continuité de l'expérience latine", in SIDI, La riforma del diritto internazionale privato italiano, Napoli, Editoriale Scientifica, 1997, p. 193; see also S. Tonolo, "Art. 51", in G. Conetti/S. Tonolo/F. Vismara (eds.), Commento alla riforma del diritto internazionale privato, Torino, Giappichelli, 2001, pp. 251-252.

15 "in base al principio del locus rei sitae".

${ }^{16}$ See S. Tonolo, “Art. 51", in G. Conetti/S. Tonolo/F. Vismara (eds.), Commento alla riforma del diritto internazionale privato, Torino, Giappichelli, 2001, p. 248.

${ }^{17}$ See A. VAcira, "Capo VIII, Diritti reali”, in F. Preite/A. Gazzanti Pugliese di Cotrone (eds.), Atti notarili nel diritto comunitario e internazionale, Vol. I, Torino, UTET, 2011, p. 1062; but see P. BENVENUTI, “Art. 51”, in S. Bariatti (ed.), Legge 31 maggio 1995, n. 218, in Nuove leggi civ. comm., 1996, pp. 1328-1329, 1333-1334, supporting the opinion whereby rights in rem in cars should be governed by the law of the place of registration.

${ }^{18}$ See S. Tonolo, "Art. 51" G. Conetti/S. Tonolo/F. Vismara (eds.), Commento alla riforma del diritto internazionale privato, Torino, Giappichelli, 2001, p. 246; P. Benvenuti, “Art. 51”, in S. Bariatti (ed.), Legge 31 maggio 1995, n. 218, in Nuove leggi civ. comm., 1996, pp. 1328-1329 and also p. 1327. 
any case, the solution adopted by Italian scholars is the same expressly offered by German autonomous private international law (see infra).

10. (iii) Art. 51 of Law 218/1995 is "completed by the operation of renvoi" under Art. 13 of the same Law: ${ }^{19}$ reference made by Art. 51 to foreign law is a so-called comprehensive reference (die Gesamtverweisung), which thus includes the private international law of the foreign legal system referred to. In the case at hand, German law would have "accepted the reference" within the meaning of Art. 13(1)(a) of Law 218/1995 ${ }^{20}$. German autonomous private international law in matters of rights in rem is found in Arts. 43 to 46 of the Introductory Law to the German Civil Code (Einführungsgesetz zum Bürgerlichen Gesetzbuche - EGBGB). ${ }^{21}$

11. In particular, Art. 43 of the EGBGB, headed "Rights in rem", can be translated as follows: "1. Rights in a property are governed by the law of the country in which the property is situated. 2. If a thing, to which rights are attached, gets into another country, these rights cannot be exercised in contradiction to the legal order of that country. 3. If rights in a thing that is moved from another country to this country, have not been acquired previously, as to such acquisition in the country, facts that took place in another country are considered as if they took place in this country".

12. Like Art. 51(1) of Law 218/1995, also Art. 43(1) of the EGBGB is based on the principle of lex rei sitae. Furthermore, also under the German conflict rule, disputes concerning the good faith acquisition of ownership in cars fall within the so-called statute of the thing (das Sachstatut). ${ }^{22}$

13. As mentioned, German autonomous private international law addresses the problem of the mobile conflict, offering a "modern and convenient solution", ${ }^{23}$ which is the same taken by Italian scholars. That solution is found in Art. 43(2) and (3) of the EGBGB: rights in the thing acquired before it was moved to another State remain subject to the law of the State where the thing was at the time of the acquisition; instead, where the thing was moved to another State before the acquisition was accomplished, the facts relating to the acquisition which took place in the State of origin are considered as if having taken place in the other State.

14. Art. 46 of the EGBGB, headed "Substantially Closer Connection", brings an exception to Art. 43 of the same EGBGB. Art. 46 can be translated as follows: "If there is a substantially closer connection with the law of a country other than that which would apply under Articles 43 and 45, then that law shall apply". Following that escape clause (die Ausweichklausel), German scholars submit that disputes concerning rights in rem in stolen things should be governed by the law of the place where the thing was stolen (lex furti). ${ }^{24}$ However, this argument does not appear to be relevant in the case at hand, since, as mentioned above, the car was not stolen as claimed by Caia, but rather bought by Tizio (see infra).

${ }^{19}$ S. Tonolo, "Art. 51" G. Conetti/S. Tonolo/F. Vismara (eds.), Commento alla riforma del diritto internazionale privato, Torino, Giappichelli, 2001, pp. 244 and 252 ("completato dall'operatività del rinvio").

${ }^{20}$ Art. 13(1)(a) of Law 218/1995 can be translated as follows: "1. When in the following Articles foreign law is referred to, reference made by the foreign private international law to the law of another State is taken into account: a) if the law accepts the reference $[\ldots] "$.

${ }^{21}$ See, briefly, A. Junker, Internationales Privatrecht, München, C.H. Beck, 2017, § 17; thoroughly, H.-P. Mansel, “Artikel 43 EGBGB”, in D. Henrich (ed.), Staudigner BGB, Köln, Otto Schmidt, 2015, version of 17 December 2018, ID., “Artikel 46 EGBGB", loc. cit., version of 10 December 2019.

${ }^{22}$ See, briefly, A. Junker, Internationales Privatrecht, München, C.H. Beck, 2017, § 17 paras. 35-36 and also 21; thoroughly, H.-P. MAnsel, “Artikel 43 EGBGB”, in D. Henrich (ed.), Staudigner BGB, Köln, Otto Schmidt, 2015, version of 10 December 2019, paras. 818 ff.; see also Oberlandesgericht (“OLG”) Koblenz, 3 July 2003, 5 U 28/02.

${ }^{23}$ L. D’Avout, "Property and proprietary rights", in J. Basedow/G. Rühl/F. Ferrari/P. de Miguel Asensio (eds.), Encyclopedia of Private International Law, Vol. III, Cheltenham-Northampton, Elgar, 2017, p. 1432

${ }^{24}$ See H.-P. Mansel, “Artikel 46 EGBGB”, in D. Henrich (ed.), Staudigner BGB, Köln, Otto Schmidt, 2015, version of 17 December 2018, paras. 63-65. 
15. Conclusively, considering that the solution adopted by Italian and German private international law in matters of rights in rem in movables appears to be identical, in the case at hand, there appears to be no issue of renvoi (beyond nor backwards). ${ }^{25}$ The judge correctly determined German law as the applicable law.

\section{3. (...) and Content thereof}

16. The judge ordered a court-appointed expert opinion on the content of the (foreign) applicable law ${ }^{26}$. The judge asked the appointed expert to answer the following question: "say [the courtappointed expert], in accordance with the German law in force, which are the conditions for good faith acquisition of ownership in a car"'27.

17. Considering that, as examined above, reference made by Art. 51 of Law 218/1995 includes the private international law of the legal system referred to, and that the substantive law so determined also governs actions against third parties, arguably the judge should have extended the scope of the expert opinion to the latter aspects.

18. In any case, the judge observed that the opinion delivered by the expert went beyond the task assigned to him, since, "[...] though specifying that these are matters of fact pertaining to the judge, it nevertheless went on examining the evidence and applying the rules $[\ldots]$ to the facts $[\ldots]$, tasks which were not entrusted to the expert and reserved to the judge"28. This notwithstanding, the judge rejected the claimant's request to have the expert opinion renewed, and instead considered the opinion, but only the part where the expert examined German law.

\section{A) Transfer of Ownership}

19. In the light of the opinion, the judge considered as relevant three paragraphs contained in the Third Book ("Law of Things"), Third Division ("Ownership"), Third Title ("Acquisition and Loss of Ownership in Movable Things") of the German Civil Code (Bürgerliches Gesetzbuch - BGB), namely $\S \S 929,932$ and 935 thereof.

20. In matters of sale and transfer of ownership the Italian and German law systems adopt two distinct models. The first model is that in force in countries where consent is sufficient to transfer ownership (so-called principio consensualistico / das Konsensualprinzip). The Italian Civil Code (C.C.) ${ }^{29}$ adopts that model. In fact, under Italian law, the general rule is that whereby the mere conclusion of the sale contract determines the transfer of ownership in the sold good to the buyer (see Art. 1376 C.C. ${ }^{30}$ ). Juxtaposed to that model is that which requires a further element (apart from consent) for the transfer

\footnotetext{
${ }^{25}$ N. Boschiero, Appunti sulla riforma del sistema italiano di diritto internazionale privato, Torino, Giappichelli, 1996, p. 177.

${ }^{26}$ Art. 14(1) of Law 218/1995 can be translated as follows: "The ascertainment of foreign law is made by the judge of his own motion. To that aim he may avail himself, apart from the instruments indicated in international conventions, of information acquired through the Ministry of Justice; he may also query experts or specialized institutions".

27 " [...] dica [il CTU], secondo le norme del diritto tedesco vigente, quali sono i presupposti per l'acquisto a non domino della proprietà di un'autovettura [...]”.

28 "[...] pur precisando che si tratta di questioni di fatto demandate al giudice, giunge comunque a valutare le prove ed applicare le norme [...] alla fattispecie [...], compito non affidato al consulente e riservato al giudicante".

${ }^{29}$ See Royal Decree 262/1942, of March $16^{\text {th }}$, Approvazione del testo del Codice civile, Gazzetta Ufficiale Serie Generale No 79 of 4 April 1942, ELI: https://www.gazzettaufficiale.it/eli/id/1942/04/04/042U0262/sg.

${ }^{30}$ Art. 1376 C.C., headed "Contracts Having In Rem Effects", can be translated as follows: "In case of contracts having as their object the transfer of ownership in a determined thing, the establishment or the transfer of a right in rem or the transfer of another right, the ownership or the right is transferred and acquired as an effect of consent expressed by the parties in accordance with the law".
} 
of ownership may take place. That second model is in force in Germany, where the BGB enshrines the so-called principle of separation (das Trennungsprinzip). Separation concerns the obligation-juristic act (das Verpflichtungsgeschäft) from the disposition-juristic act (das Verfugungsgeschäft). In fact, under German law, a purchase contract (der Kaufvertrag) alone is not sufficient to transfer property. Sale is a (merely) obligation-juristic act: it only produces obligations (and does not transfer rights in the sold thing). For ownership in the thing may be transferred (die Übertragung des Eigentums) what is also necessary is the disposition-juristic act. In the case of the sale of movable things, the disposition-juristic act consists in delivering (die Übergabe) the sold thing, accompanied by the agreement (die Einigung) between the parties to transfer ownership in the same thing.

21. The relevant paragraphs of the BGB are two, of which only the second was mentioned by the judge: $\S \S 433$ and 929 BGB. The first paragraph headed "Typical Contractual Duties in a Purchase Agreement", is contained in the Second Book ("Law of Obligations"), Eight Division ("Particular Types of Obligations"), of the BGB. $\S 433$ BGB can be translated as follows: "1. By a purchase agreement, the seller of a thing is obliged to deliver the thing to the buyer and to procure ownership in the thing. [...]". The second paragraph, $\S 929$ BGB - which, as mentioned above, is contained in the Third Book ("Ownership") of the BGB- is headed "Agreement and Delivery" and can be translated as follows: "For the transfer of ownership in a movable thing, it is necessary that the owner delivers the thing to the purchaser and both agree that ownership is to pass. If the purchaser is in possession of the thing, agreement on the transfer of the ownership suffices".

\section{B) (...) from a Person Without Title}

22. Both under Italian and German law, ownership in a movable thing can be purchased from a person without title. ${ }^{31}$ This possibility is envisaged in Art. 1153 C.C. ("Effects of Acquisition of Possession") and in § 932 BGB ("Good Faith Acquisition from a Person Without Title"). The Italian provision reads: "1. He to whom movable goods are sold by he who is not the owner, acquires ownership thereof by possession, insofar as he is in good faith at the moment of delivery and an appropriate title for the transfer of ownership exists. [...]". The German provision, § 932(1) BGB, reads: "1. As a result of a disposal carried out under $\S 929$, the acquirer becomes the owner even if the thing does not belong to the alienor, unless the acquirer is not in good faith at the time when under these provisions he would acquire ownership. [...]". Despite the similarities between the Italian and the German law system, there are two differences in the field of good faith acquisition of ownership that are relevant in the case at hand.

\section{C) (...) of Cars and Stolen Goods}

23. The first difference concerns movables registered in public registries, e.g. cars. In fact, both in Italy and Germany there exists a publicity system for cars. The general rule, in both countries, is that registration formalities do not affect the transfer of ownership in cars. In other terms, the sale (in Germany, the disposition-juristic act) transfers ownership in the car even if registration formalities are not fulfilled. However, as an exception to that general rule, under Italian law, unlike German law, ownership in cars registered with public registries cannot be acquired through good faith acquisition. ${ }^{32}$ Art. 1156

\footnotetext{
${ }^{31}$ For a comparative analysis, see C. von BAR, Gemeineuropäisches Sachenrecht, Vol. II, München, C.H. Beck, 2019, pp. $466 \mathrm{ff}$.

${ }^{32}$ However, under Italian law, movables which can be registered, but are not, can be acquired under Art. 1153 C.C. See, among others, Corte di Cassazione (“Cass."), 23 May 2018, N 12860.
} 
C.C. in fact excludes universalities of movables and movables registered in public registries from the mechanism laid down in Art. 1153 C.C. ${ }^{33,34}$

24. The second difference - observed also by the judge - is that, under German law, unlike Italian law, ownership of movables cannot be acquired through good faith acquisition if the owner has involuntarily lost possession thereof. ${ }^{35}$ In fact, $\S 935(1)$, first period, BGB reads: "1. Acquisition of property under $\S \S 932$ to 934 does not occur if the thing was stolen from the owner, is missing or has been lost in any other way. The same applies, where the owner was only the indirect possessor, if the possessor had lost the thing". ${ }^{36}$ In this respect, the judge considered a 2005 decision by the Oberlandesgericht Köln ${ }^{37}$, whereby (according to the translation accepted by the same judge): "when the owner delivers the car to be sold to a person who introduces himself as a prospective buyer, authorizing him to a drive test, this implies that delivery exclusively aims at assessing the vehicle in view of the decision whether to purchase and entails an involuntary loss of control on the thing [...] impeding the a good faith acquisition of ownership in case of a subsequent sale" 38 .

\section{D) (...) by the Good Faith Acquirer}

25. A further similarity between the Italian and the German law systems is that both require, for ownership may be transferred from the person without title, that the acquirer be in good faith (buona fede / der gute Glaube). In particular, § 932(2) BGB can be translated as follows: "The acquirer is not in good faith if he is aware, or as a result of gross negligence he is not aware, that the thing does not belong to the alienor". In this respect, the judge observed that the notion of good faith required by German law is "comparable to that contained in [Art. 1147 C.C. ${ }^{39}$ ], in that the possessor, for he may be considered as being in good faith, must take possession ignoring that he is impairing someone else's right, provided that he cannot benefit from good faith if ignorance depends on gross negligence" ${ }^{\prime 4}$.

26. The principles established by German courts on the point can be classified depending on whether the cars are new or used, and whether they are purchased from a professional car dealer or from a non-professional reseller. The case at hand is that of the purchase of a used car from a professional car dealer. In a similar case - as the judge observed -, according to German case law, good faith exists if, at

\footnotetext{
${ }^{33}$ Art. 1156 C.C., headed "Universalities of Movables and Movables Registered in Public Registries”, can be translated as follows: "The provisions of the preceding articles do not apply to universalities of movables and of movable goods registered in public registries".

${ }^{34}$ Incidentally, it is discussed among Italian scholars whether cultural goods should fall under Art. 1156 C.C., rather than under Art. 1153 C.C. See, on this discussion, M. COMPORTI, "Per una diversa lettura dell'art. 1153 cod. civ. a tutela dei beni culturali", in Scritti in onore di Luigi Mengoni. Le ragioni del diritto, Milano, Giuffrè, 1995, pp. 395 ff., contra G. MAGRI, “Acquisto a non domino e beni culturali", Riv. dir. civ., 2013, N 3, pp. $741 \mathrm{ff}$.

${ }^{35}$ For a comparative analysis of good faith acqusition of ownership in stolen goods under Italian, French and German law, see G. MAGRI, "Usucapione ed acquisto a non domino nel prisma della Convenzione europea dei diritti dell'uomo", Riv. dir. civ., 2014, pp. 1402-1428.

36 See C. Meller-Hannich, "BGB § 935", in H. Grziwotz/A. Keukenschrijver/G. Ring (eds.), BGB Sachenrecht, Baden-Baden, Nomos, 2016, para. 8; H. Oechsler, “BGB § 935”, in F.-J. Säcker/R. Rixecker/H. Oetker/B. Limperg (eds.), Münchener Kommentar zum Bürgerlichen Gesetzbuch, München, C.H. Beck, 2020, para. 6; F. KLINCK, “BGB § 935”, in B. Gsell/W. Krüger/S. Lorenz/C. Reymann (eds.), beck-online.GROSSKOMMENTAR BGB, version of 1 January 2020, para. 9.

${ }^{37}$ OLG Köln, 18 April 2005, 19 U 10/05, BeckRS, 2005, p. 8686.

38 "qualora il proprietario consegni il veicolo in vendita ad un soggetto che si presenta come potenziale acquirente autorizzandolo ad una prova su strada, ciò implica che la consegna sia finalizzata unicamente alla conoscenza del veicolo in preparazione della decisione di acquisto e comporta una perdita involontaria del dominio sul bene [...] impedendo l'acquisto a non domino nel caso di successiva vendita".

${ }^{3}$ Art. 1147 C.C., headed "Good Faith Possession", can be translated as follows: "1. The good faith possessor is he who possess ignoring to impair someone else's right. 2. Good faith is not beneficial if ignorance depends on gross negligence. [...]".

40 "paragonabile a quella contenuta nel nostro codice civile all'art. 1147, laddove il possessore, perché possa essere considerato in buona fede, deve possedere ignorando di ledere l'altrui diritto, fermo restando che la buona fede non giova se l'ignoranza dipende da colpa grave".
} 
the time of purchase, the buyer has at least examined the car's registration book. Only if there are serious reasons to doubt as to the lawful origin of the car, then the buyer must undertake further investigations. Instead, in the case of a used car purchased from a non-professional reseller, the buyer must examine the registration book and check that the name mentioned therein is that of the seller. ${ }^{41}$

27. As summarized by the judge: "[I]n other words, the registration book must mention the seller's name unless the seller is not a professional car dealer, since, when one purchases from a professional car dealer, you don't expect the seller's registration, which is unusual, and the buyer may rely on the fact that the car dealer has been appointed to sell by the person mentioned in the certificate" ${ }^{" 42} .{ }^{43}$

\section{Transaction Chain}

28. The case at hand involves a chain of transactions, namely of three contracts for the sale of the disputed Lamborghini, respectively concluded between A) Caia and Tizio, B) Tizio and the car dealer, C) the car dealer and Hans.

\section{A) Caia and Tizio}

29. It must be preliminarily noted that the judge ascertained that Tizio had not stolen the Lamborghini, but rather bought the car from Caia, though paying the price with an uncovered cheque. The sale contract between Caia and Tizio was a purely domestic contract, governed by Italian law.

30. Reading the decision, it appears that the judge assumed that the sale contract was valid and that Tizio's payment with the uncovered cheque amounted to nothing more than a contractual non-performance. However, it must be noted that paying with an uncovered cheque may amount to a criminal offence, namely fraud under Art. 640 of the Italian Criminal Code ${ }^{44}$ (and, incidentally, also under Art. 263 of the German Criminal Code ${ }^{45}$ ).

30. According to the Corte di Cassazione, a sale contract concluded by the buyer, who cheated the seller by paying with an uncovered check, is null (nullo) under Art. 1418 C.C. ${ }^{46}$ Instead, according to a different and juxtaposed opinion, paying with an uncovered cheque entails mere voidability (annullabilità) of the relevant contract under Art. 1427 C.C. ${ }^{47,48}$ If one follows the first opinion, then the sale contract between Caia and Tizio did not transfer ownership in the car to the delinquent buyer. Instead, if the second opinion is followed, considering that (apparently) the sale contract had not been avoided, the

${ }^{41}$ On good faith acquisition of ownership of cars under $\S 932$ BGB, see, thoroughly, H. OECHSLER, "BGB § 932", in F.J. SäCKer/R. RiXeCKer/H. OetKer/B. Limperg (eds.), Münchener Kommentar zum Bürgerlichen Gesetzbuch, München, C.H. Beck, 2020, paras. 55-59.

42 "In altre parole, la carta di circolazione deve contenere il nome del venditore a meno che il cedente non sia un rivenditore di autoveicoli perché quando si acquista da un rivenditore non ci si aspetta la registrazione del venditore, che non è usuale, potendo l'acquirente fare affidamento nella circostanza che il venditore è stato incaricato della vendita dalla persona indicata nel certificato".

${ }^{43}$ The judge considered two decisions cited in the court-appoint expert's opinion: OLG Köln, 14 July 2017, 6 U 177/16, BeckRS, 2017, p. 118318; and Bundesgerichtshof (“BGH”), 13 December 2013, V ZR 58/13, NJW, 2014, p. 1524.

${ }^{44}$ See Cass., 20 February 2014, $\mathrm{N}^{\circ} 10850$.

45 See BGH, 26 July 1972, 2 StR 62/72.

${ }^{46}$ See Cass., 15 June 1999, N 5917, Contratti, 1999, N 10, p. 902.

${ }^{47}$ See Tribunale di (“Trib.”) Bergamo, 22 April 2008; see also Cass., 16 June 2011, № 13187, Giur. It., 2012, ํ 7, p. 1578.

${ }^{48}$ Similarly, under German law declaration of will affected by fraud is "only" voidable (anfecthbar) according to $\S 123$ BGB, and not per se null (nichtig). See D. Wendtland, "BGB § 134", in H.G. Bamberger/H. Roth/W. Hau/R. Poseck (eds.), BeckOK BGB, München, C.H. BeCK, version of 1 November 2019, 42 $2^{\text {nd }}$ end., para. 18; C. Armbrüster, "BGB $\S 134$ ", in F.J. SäCKER/R. RiXeCKer/H. OetKer/B. Limperg (eds.), Münchener Kommentar zum Bürgerlichen Gesetzbuch, München, C.H. Beck, 2020, paras. 50-62. 
same contract transferred ownership. Therefore, depending on the opinion preferred, Tizio either did or did not become the car's owner. This aspect was not considered by the judge.

\section{B) Tizio and the Car Dealer}

31. The sale contract between Tizio and the car dealer was an international sale contract, apparently falling within the scope of the 1980 Vienna Convention ${ }^{49}$. However, as mentioned above, issues relating to the transfer of ownership in sold goods are excluded from the scope of that Convention. Rather, those issues are governed by the law applicable in accordance with the private international law of the forum; in the case at hand, as examined above, by the lex rei sitae. It can be reasonably assumed that, at the time of the sale, the car was in Germany. Therefore, there are three cases: (i) either Tizio became the car's owner (under Italian law) and then transferred ownership to the car dealer under $\S 929$ BGB; or (ii) Tizio did not become the car's owner (under Italian law), but the car dealer was in good faith and thus acquired ownership under $\S 932$ BGB; or (iii) Tizio did not become the car's owner (under Italian law), the car dealer was not in good faith and thus did not acquire ownership under $\S 932$ BGB. Considering that, when Tizio sold the car to the car dealer, the car's registration book still mentioned Caia as the owner, one could question whether the car dealer was actually in good faith within the meaning of $\S 932$ BGB. But, these aspects were not considered by the judge, either.

\section{C) The Car Dealer and Hans}

32. The sale contract between the car dealer and Hans was a domestic contract, governed by German law. ${ }^{50}$ If the car dealer became the car's owner (either under $\S 929$ or $\S 932$ BGB), then, in turn, ownership was transferred to Hans under $\S 929$ BGB. Not even this aspect was considered by the judge. Instead, if the car dealer did not become the car's owner, in any case Hans acquired ownership under $\S$ 932 BGB. In fact, the judge ascertained that, at the time of the sale, the car dealer had shown the car's registration book: Hans was in good and thus acquired ownership in the car under $\S 932$ BGB.

\section{Final Remarks}

33. The judge concluded that Hans had become the car's owner, following a good faith acquisition of ownership in accordance with German law.

34. The judge's decision is not wholly convincing: if, as the judge appears to have assumed, Tizio acquired ownership in the Lamborghini under Italian law, in turn Hans should have acquired ownership in the car from the car dealer under $\S 929$, and not under $\S 932$ BGB. In effect, it appears that Hans could be considered a good faith acquirer only if it is submitted that neither Tizio nor the car dealer had acquired ownership in the car. Conclusively, the judge should have perhaps more coherently determined Hans as the owner of the car under $\S 929$, rather than as a good faith acquirer under $\S 935$ BGB.

\footnotetext{
${ }^{49}$ Incidentally, on international sale in relations between Germany and Italy, see E. JAYME (ed.), La compravendita internazionale di beni mobile nei rapport fra Italia e Germania, Padova, CEDAM, 1990.

${ }^{50}$ See Trib. Novara, 28 June 2017, Riv. dir. int. priv. e proc., 2019, № 3, pp. 614-616.
} 